\title{
The Politics of Nationalism and Ethnicity
}




\title{
The Politics of Nationalism and Ethnicity
}

\author{
James G. Kellas
}

Macmillan Education 
ISBN 978-0-333-45257-8 ISBN 978-1-349-21527-0 (eBook)

DOI 10.1007/978-1-349-21527-0

(C) James G. Kellas 1991

Softcover reprint of the hardcover 1st edition 1991 978-0-333-45256-1

All rights reserved. For information, write:

Scholarly and Reference Division,

St. Martin's Press, Inc., 175 Fifth Avenue

New York, NY 10010

First published in the United States of America in 1991

ISBN 978-0-312-06159-3

Library of Congress Cataloging-in-Publication Data

Kellas, James G.

The politics of nationalism and ethnicity / James G. Kellas.

p. $\quad \mathrm{cm}$.

Includes bibliographical references and index.

ISBN 978-0-312-06159-3

1. Nationalism. 2. Ethnicity - Political aspects. I. Title. JC311.K43 1991

$320.5^{\prime} 4-\mathrm{dc} 20$ 


\section{Contents}

List of Tables vii

Acknowledgements $\quad$ ix

$\begin{array}{ll}\text { Introduction } & 1\end{array}$

1 Ethnicity and Human Nature 8

2 Nationalism as Ideology 20

3 The Evolution of Nationalism: theories 34

4 Ethnic and Social Nationalism 51

5 Nationalist Movements and Ethnic Politics: forms and periods $\quad 72$

6 Nationalism in the 'First World' 86

Western Europe $\quad 86$

Quebec $\quad 94$

Ethnic politics in the US and Britain 98

7 Nationalism in the 'Second World' 106

The USSR 107

Yugoslavia 114

8 Nationalism in the 'Third World', South Africa, and the Middle East 117

Sri Lanka and the Indian sub-continent 118

Black Africa 123

South Africa and Apartheid 126

Zionism and Palestinian Nationalism 129 
9 Cultural Pluralism and the Politics of Accommodation

10 Nationalism and International Relations

11 Conclusion: An Integrated Theory of the Politics of Nationalism and Ethnicity

Bibliography

Index 


\section{List of Tables}

1.1 Scottish national identity, $1986 \quad 17$

1.2 Catalan national identification, $1979 \quad 18$

3.1 Politics, the Economy, and Culture and nationalism 35

4.1 Ethnic and social nationalism 54

$\begin{array}{lll}6.1 & \text { Catalan elections } & 90\end{array}$

6.2 Basque elections 91

10.1 'Net favourability' of attitudes in Britain
and France towards other countries

11.1 Types of nationalism 166 


\section{Acknowledgements}

I first studied nationalism as an undergraduate student of Joseph Frankel at the University of Aberdeen in 1957-58, and later specialised in the study of Scottish politics as a university lecturer. Once more, the subject of nationalism came to the fore, in the form of Scottish nationalism. As a Visiting Professor of Political Science at the University of Pittsburgh in 1985-86, I taught a course on nationalism generally, and had regular discussions on the subject with Richard Cottam (an expert on Middle East nationalism), Dennison Rusinow (an historian with a particular interest in Balkan nationalism), and Christina Paulston (a linguist specialising in language survival). These sessions broadened my perspective considerably.

At the University of Glasgow, I have kept up a continuous discourse on nationalism with colleagues, many of whom are experts on political theory and the study of particular areas of the world. Most of these will perhaps be surprised at the content of this book, and perhaps alarmed. I hope they do not mind my thanking them here, but they are of course not a party to what I have written.

Special thanks are due to Mrs Avril Johnstone, who coped with the frequent revisions during the production of the typescript. 